\title{
An estimate of the area of occupancy and population size of Brachycephalus tridactylus (Anura: Brachycephalidae) to reassess its conservation status, with a proposal for conservation measures
}

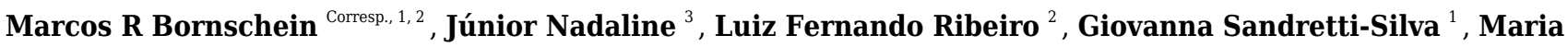 \\ Fernanda Ferreira Rivas ${ }^{1}$, Bruno de Morais Guerra ${ }^{1}$, Larissa Teixeira ${ }^{1}$ \\ 1 Instituto de Biociências, Universidade Estadual Paulista, São Vicente, São Paulo, Brazil \\ 2 Mater Natura - Instituto de Estudos Ambientais, Curitiba, Paraná, Brazil \\ 3 Departamento de Zoologia, Universidade Federal do Paraná, Curitiba, Paraná, Brazil \\ Corresponding Author: Marcos R Bornschein \\ Email address: marcos.bornschein@unesp.br
}

Background. We are experiencing a global crisis in conservation, which has led to the prioritization of targets, such as nations, regions, and animal groups, which are necessary while resources are disputed. Brazil is a priority not only because of its megadiversity, high rates of endemism, and frequent descriptions of new species but also because of its high levels of deforestation. Among the species groups prioritized for conservation is the anurans (Amphibia: Anura), the population of which is severely declining. One group of anurans is the genus Brachycephalus, which includes 37 endemic species in the Brazilian Atlantic Rainforest. Some of these species have highly restricted distributions ( $<100 \mathrm{ha}$ ). Thirty new species have been described since 2000 , and $55.3 \%$ of all species are threatened with extinction. Brachycephalus tridactylus was only recently described and remains restricted to its type locality. Because of its reduced geographical distribution $\left(0.41 \mathrm{~km}^{2}\right)$, it has been proposed to be considered as Vulnerable. The objective of this study is to reevaluate the conservation status of Brachycephalus tridactylus and propose conservation measures. Methods. We searched for new populations during 2016-2020, evaluated in loco impacts and potential impacts on the species' population, and performed an analysis of the density of this population and estimated its size. International Union for Conservation of Nature (IUCN) criteria were used to assess the conservation status of the species. Results. We recorded the species in seven new localities (from 715-1,140 m above sea level) in the state of São Paulo up to $33 \mathrm{~km}$ from the type locality of the species (in state of Paraná). We estimated the area of occupancy as $148.44 \mathrm{~km}^{2}$, densities as one calling male per $4.05 \mathrm{~m}^{2}$ and $130.00 \mathrm{~m}^{2}$, and a total population size of $4,429,722$ adult individuals. Based on our finding, we proposed three lines of management: 1) formation of 
fire brigades, 2) management of residents' mules in the conservation unit and surrounding areas, and 3) management of degraded areas. We recommend changing the species' conservation status from Vulnerable to Endangered because of its fragmented distribution and decline in the area of occupancy and in the quality of its habitat. Our results have expanded the species previous geographic distribution and delimited areas without previous records. Our estimates of population density and size are in accordance with those verified for congeners. The conservation of this species benefits the environments and other species that inhabit them, being, therefore, strategic for receiving conservation actions that will spread throughout the ecosystem. 
1 An estimate of the area of occupancy and population

2 size of Brachycephalus tridactylus (Anura:

3 Brachycephalidae) to reassess its conservation

4 status, with a proposal for conservation measures

Marcos R. Bornschein ${ }^{1,2}$, Júnior Nadaline ${ }^{3}$, Luiz Fernando Ribeiro ${ }^{2}$, Giovanna Sandretti-Silva ${ }^{1}$, Maria Fernanda Ferreira Rivas ${ }^{1}$, Bruno de Morais Guerra ${ }^{1}$, Larissa Teixeira ${ }^{1}$

${ }^{1}$ Departamento de Ciências Biológicas e Ambientais do Instituto de Biociências - Câmpus do

Litoral Paulista, Universidade Estadual Paulista, São Vicente, São Paulo, Brazil

${ }^{2}$ Mater Natura - Instituto de Estudos Ambientais, Curitiba, Paraná, Brazil

${ }^{3}$ Departamento de Zoologia, Universidade Federal do Paraná, Curitiba, Paraná, Brazil

Corresponding Author:

Marcos R. Bornschein

${ }^{1}$ Praça Infante Dom Henrique, s/n, São Vicente, São Paulo, CEP 11330-900, Brazil.

${ }^{2}$ Rua Emiliano Perneta, 297, Curitiba, São Paulo, CEP 80010-050, Brazil.

Email address: marcos.bornschein@unesp.br

\section{Abstract}

Background. We are experiencing a global crisis in conservation, which has led to the prioritization of targets, such as nations, regions, and animal groups, which are necessary while resources are disputed. Brazil is a priority not only because of its megadiversity, high rates of endemism, and frequent descriptions of new species but also because of its high levels of deforestation. Among the species groups prioritized for conservation is the anurans (Amphibia: Anura), the population of which is severely declining. One group of anurans is the genus Brachycephalus, which includes 37 endemic species in the Brazilian Atlantic Rainforest. Some of these species have highly restricted distributions $(<100 \mathrm{ha})$. Thirty new species have been described since 2000 , and $55.3 \%$ of all species are threatened with extinction. Brachycephalus tridactylus was only recently described and remains restricted to its type locality. Because of its reduced geographical distribution $\left(0.41 \mathrm{~km}^{2}\right)$, it has been proposed to be considered as Vulnerable. The objective of this study is to reevaluate the conservation status of populations during 2016-2020, evaluated in loco impacts and potential impacts on the species' population, and performed an analysis of the density of this population and estimated its size. International Union for Conservation of Nature (IUCN) criteria were used to assess the conservation status of the species. Results. We recorded the species in seven new localities (from 715-1,140 m above sea level) in the state of São Paulo up to $33 \mathrm{~km}$ from the type locality 
as one calling male per $4.05 \mathrm{~m}^{2}$ and $130.00 \mathrm{~m}^{2}$, and a total population size of 4,429,722 adult individuals. Based on our finding, we proposed three lines of management: 1) formation of fire brigades, 2) management of residents' mules in the conservation unit and surrounding areas, and 3) management of degraded areas. We recommend changing the species' conservation status from Vulnerable to Endangered because of its fragmented distribution and decline in the area of occupancy and in the quality of its habitat. Our results have expanded the species previous geographic distribution and delimited areas without previous records. Our estimates of population density and size are in accordance with those verified for congeners. The conservation of this species benefits the environments and other species that inhabit them, being, therefore, strategic for receiving conservation actions that will spread throughout the ecosystem.

\section{Introduction}

Anura is a priority group for conservation assessments because of the high proportion of endangered species and rapid increase in descriptions of new taxa (Tapley et al., 2018). This priority is particularly urgent in countries with extensive deforestation, such as Brazil (Tapley et al., 2018). One of the Brazilian anuran endemic genera that has received increasing attention is Brachycephalus Fitzinger, 1826. It includes 37 endemic species of the Atlantic Rainforest (Bornschein, Ribeiro \& Pie, 2021; Frost, 2021), 30 of which have been described since 2000. Equally striking is the percentage of species $(55.3 \%)$ considered threatened with extinction (Bornschein, Pie \& Teixeira, 2019). Moreover, 26.3\% of the remaining species have been considered Data Deficient (Bornschein, Pie \& Teixeira, 2019), which may be reassessed in the future as threatened with extinction. Finally, two species described after Bornschein, Pie \& Teixeira (2019) have not yet been assessed for their conservation status (Condez et al., 2021; Nunes et al., 2021).

Brachycephalus includes small diurnal species (less than $2.5 \mathrm{~cm}$ in snout-vent length) that inhabit the leaf litter on forest floors and are usually heard rather than seen (Pombal \& Gasparini, 2006; Condez et al., 2014; Ribeiro et al., 2015; Bornschein et al., 2016a). Because the species depends on a cold, humid climate, they find suitable conditions at high altitudes, such as on mountaintops (Pie et al., 2013; Bornschein et al., 2016a). These high elevations are surrounded by lower altitudes with warmer climates, promoting speciation in the recent past (Bornschein et al., 2016a; Firkowski et al., 2016; Pie et al., 2018a; Condez, Haddad \& Zamudio, 2020) and acting as sky islands (sensu McCormack et al., 2009). This pattern explains the small geographic distributions of most species of Brachycephalus (Bornschein et al., 2016a), as well as other groups of reptiles, amphibians, and birds (e.g., Carnaval et al., 2014; Pulido-Santacruz et al., 2016; Oliveira et al., 2021). The small distributions in conjunction with losses in areas of occupation and quality of habitats are the main cause of threats to the species (Bornschein, Pie \& Teixeira, 2019).

One Brachycephalus species that was recently described and considered threatened with extinction (Bornschein, Pie \& Teixeira, 2019) is B. tridactylus. It was described in 2012 based on seven individuals collected in 2007 and 2008 on the northern coast of Paraná at 900-930 m 
79

80

81

82

83

84

85

86

87

88

89

90

91

92

93

94

95

96

97

98

99

100

101

102

103

104

105

106

107

108

109

110

111

112

113

114

115

116

117

118

above sea level (a.s.l.; Garey et al., 2012). Subsequently, its type locality was corrected, and the altitude of occurrence changed to 880-910 m a.s.1. (Bornschein et al., 2015a). Based on new field data regarding the type locality, the recorded altitudinal range has been increased to 805$910 \mathrm{~m}$ a.s.1. (Bornschein et al., 2016a); hence, the geographic distribution was estimated at 0.41 $\mathrm{km}^{2}$ (Bornschein et al., 2016a). This small geographic distribution led to a proposal to classify the species as Vulnerable (Bornschein, Pie \& Teixeira, 2019).

From 2016-2021, our research group conducted fieldwork on Brachycephalus around the type locality of $B$. tridactylus. In this article, we report the results of our research on the geographic distribution, population size, and impacts on habitat of this species. We also review and improve information known to support the conservation status of B. tridactylus and propose management strategies for its conservation.

\section{Materials \& Methods}

\section{Study Region and Field Procedures}

We delimited the maximum study region as a circle with a $60 \mathrm{~km}$ radius around the type locality of the species (according to Bornschein et al. [2015a]; Fig. 1). To improve the spatialization of the field effort, we delimited the approximate area of the Dense Ombrophilous Forest (Floresta Ombrófila Densa, sensu Veloso, Rangel-Filho \& Lima [1991]) over 700 m a.s.1. (+/- 20 m) of this region, defined additional circles with radii of $10-50 \mathrm{~km}$, and divided all the circles into four quadrants of $90^{\circ}$ each (Fig. 1). We tried to sample most of the quadrants with forests from about $700 \mathrm{~m}$ a.s.1. The inaccessibility of mountainous and other high-altitude areas, however, limited the sampling. Although we conducted most of our research at sampling points that were accessible by secondary roads and trails, we often entered dense vegetation without trails. We conducted fieldwork from the end of 2016 to early 2020 in the spring and summer months (i.e., from October to March), and also in September 2021.

At each locality of record, we took geographical coordinates using a GPS device (Garmin Etrex $^{\circledR} 10$ and Garmin GPSMAP ${ }^{\circledR} 60 \mathrm{CSx}$; DATUM WGS84), identified and described the environmental impacts, and identified the type of vegetation according to the classification criteria for Brazilian vegetation (Veloso, Rangel-Filho \& Lima, 1991). We were careful to classify the secondary vegetation that had not yet regenerated to the forest stage (see Bornschein, 2015). We recorded the altitude for each geographic coordinate using Google Earth Pro and rounded it to the nearest $5 \mathrm{~m}$, according to Bornschein et al. (2016a).

Specimens were anesthetized and euthanized using 2\% lidocaine hydrochloride, fixed in 10\% formalin, stored in a 70\% ethyl alcohol solution, and deposited in the herpetological collections of the Museu de História Natural Capão da Imbuia (MHNCI), Curitiba, Paraná, Brazil. To ensure their identification, we compared these specimens with the original description of B. tridactylus (Garey et al., 2012) and with specimens we collected from its type locality and deposited in the MHNCI and the Célio F.B. Haddad collection (CFBH), Departamento de Zoologia, Universidade Estadual Paulista, Rio Claro, São Paulo, Brazil. We also compared advertisement call recordings of specimens with those from the type locality of B. tridactylus (Bornschein et 
119 al., 2019a). Collection permits for this study were granted by Instituto Chico Mendes de 120 Conservação da Biodiversidade (ICMBIO; \#55918-1, \#58088-2, \#72845-1) and Secretaria do

121 Meio Ambiente, Instituto Florestal, Coordenadoria de Tecnologia de Informação e Comunicação 122 (COTEC; \#693/2017 D63/2017 FN).

123

124

125

126

127

128

129

130

131

132

133

134

135

136

137

138

139

140

141

142

143

144

145

146

147

148

149

150

151

152

153

154

155

156

157

158

\section{Population Size Estimation}

We estimated the number of calling males according to Bornschein et al. (2016b), Ribeiro et al. (2017), Pie et al. (2018b), and Bornschein, Teixeira \& Ribeiro (2019). We delimited a polygonal area in which individuals were calling and used tapes to mark their positions. When no new materials were added after about $1 \mathrm{~h}$, we counted all the tapes and measured the polygon, which resulted in an estimate of individuals per sampled area. Assuming a proportion of one female per male (Bornschein, Teixeira \& Ribeiro, 2019), we extrapolated the density to the entire geographical distribution area of the species (e.g., Bornschein, Pie \& Teixeira, 2019). Since Brachycephalus are usually found in mountainous regions with difficult access, we did not randomize the sites for the census.

\section{Conservation}

In the field, we observed the incidence of impacts or possible impacts that affected or could affect populations of B. tridactylus by making the habitat unavailable, reducing the quality of the habitat, and/or eliminating entire patches of habitat, as historical and recent losses of forest coverage, fires, the suppression of vegetation beside roads, vegetation clearance below power lines, wood logging, edge effects, the construction of power plants and housing, the introduction of invasive alien plants, and extensive cattle ranching (Bornschein et al., 2015b, 2016b; Garey \& Provete, 2016; Bornschein, Pie \& Teixeira, 2019; Bornschein, Teixeira \& Ribeiro, 2019; Pie \& Ribeiro, 2015; Ribeiro et al., 2015, 2017; Pie et al., 2018b; Nunes et al., 2021).

\section{Conservation Status}

We assessed the conservation status of the species according to IUCN (2012) and IUCN Standards and Petitions Committee (2019) criteria. However, we first determined the appropriate path for the assessment from the six pathways proposed by Bornschein, Pie \& Teixeira. (2019). These paths allowed for possibility of assessment of the conservation status based on the number of records of the species, the knowledge of the altitudinal range of its occurrence, and the geographic distribution, regardless of whether it was confined to a mountain massif.

Geographical distribution was determined in two ways: 1) by the space bounded by the lowest and highest registration altitude isolines and 2) by the space determined by connecting the extreme records using the minimum convex polygon method (MCP; Mohr [1947]). In both cases, inappropriate habitats, such as pasture lands, monoculture tree plantations, urban areas, croplands, and water surfaces, were removed from the distribution mapping, according to Reinert, Bornschein \& Firkowski (2007).

Peer) reviewing PDF | (2021:07:63242:2:0:NEW 23 Nov 2021) 
159 Results

\section{Habitat, Geographic Distribution, and Altitudinal Distribution}

161

162

163

164

165

166

167

168

169

170

171

172

173

174

175

176

177

178

179

180

181

182

183

184

185

186

187

188

189

190

191

192

193

194

195

196

197

198

We found Brachycephalus tridactylus in seven new localities, all of which were situated in the state of São Paulo, southeastern Brazil (Table 1; Fig. 2). Vouchers (Table 1) showed a general orange color with green dots on the sides of the body (Fig. 3A), which aligned with the original description of coloration and with seven specimens we collected in the type locality (MHNCI 10294, 10729-30; CFBH 43887-90; Fig. 3B), and they presented an advertisement call with only isolated notes. Also, we did not record the species at 15 localities (Table S1).

We recorded the species at 715-1,140 m a.s.l. (Table 1) in Montane Dense Ombrophilous Forest (Floresta Ombrófila Densa Montana), but we were unable to reach an altitude above 1,140 $\mathrm{m}$ a.s.l. We did not record the species in secondary vegetation not yet regenerated in forest, in transitional forest between Montane Dense Ombrophilous Forest and Mixed Montane Ombrophilous Forest (Floresta Ombrófila Mista Montana), or in the Mixed Montane Ombrophilous Forest itself.

The seven new localities and the type locality of the species were enclosed in a minimum convex polygon (Fig. 4), from which we excluded areas at lower altitudes (40-714 m a.s.1.) or higher altitudes $(1,141-1,300 \mathrm{~m}$ a.s.l.) than those of the recorded altitudinal range of the species, as well as areas where the original forest had been replaced or removed but was still regenerating and was not yet at the forest stage. This resulted in an area of occupancy of $148.44 \mathrm{~km}^{2}(14,843.6$ ha; Fig. 4), $78.2 \%\left(116.0 \mathrm{~km}^{2}\right)$ of which was in São Paulo state, and the remaining area (32.4 $\left.\mathrm{km}^{2}\right)$ in Paraná state.

\section{Density and Population Size}

At Torre Embratel (see Table 1), we counted calling males within a polygon of $32.4 \mathrm{~m}^{2}$ $\left(24^{\circ} 52^{\prime} 46^{\prime \prime} \mathrm{S}, 48^{\circ} 15^{\prime} 30^{\prime \prime} \mathrm{W}\right)$ for $3 \mathrm{~h}(9: 50-12: 50 \mathrm{~h})$ on January 27,2018 and in a polygon of $1,300 \mathrm{~m}^{2}\left(24^{\circ} 52^{\prime} 45^{\prime \prime} \mathrm{S}, 48^{\circ} 15^{\prime} 27^{\prime \prime} \mathrm{W}\right)$ for almost $3 \mathrm{~h}(9: 50-12: 40 \mathrm{~h})$ on September 7, 2021 . There were 8 and 10 calling males per counting —one per $4.05 \mathrm{~m}^{2}$ and $130.00 \mathrm{~m}^{2}$, respectively (a mean of one male per $67.02 \mathrm{~m}^{2}$ ). Assuming a proportion of one female per male, the density of one adult individual per $33.51 \mathrm{~m}^{2}$ implied a population of 4,429,722 adult individuals.

\section{Impacts on Populations}

The largest part of the area of occupancy of B. tridactylus was within the Parque Estadual do Rio Turvo (State Park Turvo River), in the municipalities of Barra do Turvo and Cajati, São Paulo $\left(112.8 \mathrm{~km}^{2} ; 75.7 \%\right.$ of total area of occupancy). Approximately $0.24 \%\left(3.3 \mathrm{~km}^{2}\right)$ was within the Reserva Natural Salto Morato (Natural Reserve Salto Morato) - a private park in the municipality of Guaraqueçaba, Paraná. The areas with adequate conditions that could have been included in the area of occupancy of the species, but were not due to deforestation, were in the state of São Paulo within the limits of the Parque Estadual do Rio Turvo. In this conservation unit, there was a historical reduction in the area of occupancy of the species due to swiddens, conversions to pasture land, constant losses due to the spread of forest fires started for the 
199

200

201

202

203

204

205

206

207

208

209

210

211

212

213

214

215

216

217

218

219

220

\section{Discussion}

\section{Geographic Distribution}

223

224

225

226

227

228

229

230

231

232

233

234

235

236

237 forest interior.

\section{Conservation Status} of habitat (iii) [EN B2ab(ii,iii)]. et al., 2013).

revitalization of pasture land, and logging (Fig. 5). Also, a recent impact has been a reduction in the quality of the habitat. Forest areas on the edge of deforested areas suffer from the edge effect, which locally reduces the occurrence of $B$. tridactylus by a few meters from the edge toward the

We highlighted the intense impacts of palmiteiros (palm heart [Euterpe edulis Mart.] harvesters; Fig. 6) who (i) cut almost all adult individuals of this species of palm, (ii) change the structure of the lower strata of vegetation to cut the palm hearts, and (iii) open relatively wide trails to allow the passage of mules and their loads of palm hearts, which are transported in bundles on the sides of the animals. There is no area in the eastern Atlantic Forest where palm hearts are not targeted by palmiteiros, even in conservation units. In all the areas that we accessed on the Parque Estadual do Rio Turvo, we saw cut palm hearts, even away from roads. To access up to 1,080 $\mathrm{m}$ of altitude from Morro do Bisel, for example, we walked $2.1 \mathrm{~km}$ into the forest without trails, where we saw cut palm hearts up to $950 \mathrm{~m}$ a.s.1. We also observed frequently used palmiteiro trails and campsites up to $900 \mathrm{~m}$ a.s.1.

Based on the IUCN criteria for classifying the conservation status of species, we propose that $B$. tridactylus should be classified as Endangered. The criteria are as follows: geographic range (B) in the form of area of occupancy (B2) are severely fragmented (a; Fig.4) with continuous decline observed, inferred, or projected (b) in the area of occupancy (ii), and area, extent and/or quality

The systematic search resulted in several new records that extended the geographical distribution of B. tridactylus $33 \mathrm{~km}$ to the north. The presence of B. tridactylus in the south of São Paulo was in an adequate climate continuous with the mountains and plateaus in Paraná (see Fig. 3e in Pie

We conducted extensive sampling in the vast study region - a circle with a $60 \mathrm{~km}$ radius around the type locality of the species (Fig. 1). Also, the species was unrecorded in another 15 localities (Table S1), suggesting that its current estimated geographic distribution is realistic. Large distributional extensions are not expected to be detected in future research. Although there is an environmental continuum in the southwest of the study region, where the species could be recorded (Fig. 1), the area is occupied by B. brunneus, which has no indicated sympatry with $B$. tridactylus (Bornschein, Pie \& Teixeira, 2019). New localities of records, however, should be made within the study region, perhaps in the Serra da Virgem Maria (2506'38'S, 48 31'42”W), on the border of São Paulo and Paraná states, at 1,487 $\mathrm{m}$ a.s.l. The area has never been explored by scientists. The difficulty in accessing mountains limits the search for new populations of Brachycephalus, since it requires bold explorations similar to the exploration we conducted to 
238

239

240

241

242

243

244

245

246

247

248

249

250

251

252

253

254

255

256

257

258

259

260

261

262

263

264

265

266

267

268

269

270

271

272

273

274

275

276

reach Morro do Bisel. Our team conquered and named this mountain after two years of searching for the best access point, which required developing $2.1 \mathrm{~km}$ of trails.

The occurrence of Brachycephalus tridactylus overlaps that of B. sulfuratus at least in Bairro Rio Vermelho, Morro do Bisel, Serra do Pinheiro, and Torre Embratel. These species have been registered less than $20 \mathrm{~cm}$ from each other. There are a few cases of sympatry between Brachycephalus species (Bornschein et al., 2016a, 2021), most of which include B. sulfuratus (Bornschein et al., 2016a).

\section{Density and Population Size}

The density of calling males per $\mathrm{m}^{2}$ estimated for B. tridactylus resembles that of $B$. curupira in areas with lower abundances of individuals (Ribeiro et al., 2017); is lower than that of $B$. albolineatus at higher altitudes (one calling male for every $3-4 \mathrm{~m}^{2}$, Bornschein et al. [2016b]), $B$. mirissimus (one calling male for every $14.5 \mathrm{~m}^{2}$; Pie et al. [2018b]), and B. fuscolineatus (one calling male for every $4 \mathrm{~m}^{2}$, Bornschein, Teixeira \& Ribeiro [2019]); and is higher than that of $B$. albolineatus at lower altitudes (one calling male for every $100 \mathrm{~m}^{2}$; Bornschein et al. [2016b]). The population size of $B$. tridactylus is greater than that of $B$. albolineatus; lower than that of $B$. didactylus, B. sulfuratus, and B. pitanga, and well above that of, B. fuscolineatus (Bornschein, Pie \& Teixeira, 2019).

\section{Conservation}

Brachycephalus tridactylus occurs in forests, but we did not record this species at forest edges in deforested areas. The same was verified for B. fuscolineatus (Bornschein, Teixeira \& Ribeiro, 2019), possibly due to microclimate changes, such as the reduced humidity averages and increased temperature averages caused by the disruption of forest structure at the edges (Magnago et al., 2015). We also did not record B. tridactylus in regenerating tree formations that had not yet reached the forest stage. This finding agreed with most occurrences of species of the genus; only five species have been recorded in secondary vegetation not yet regenerated to a forest (Bornschein et al., 2019b).

The revision of the conservation status of $B$. tridactylus occurred through pathway \#5 of Bornschein, Pie \& Teixeira. (2019). This scrutiny changed the previous classification of the species as Vulnerable (Bornschein, Pie \& Teixeira, 2019) to Endangered, a higher threat category. The cause of threat for the species was previously limited to the reduced geographical distribution, but reduced habitat and reduced quality of habitat have also now been incorporated as threats. Both factors have also affected other species of the genus, such as $B$. mariaeterezae and B. quiririensis (Bornschein, Pie \& Teixeira, 2019). Several areas that could have contributed to the area of occupancy of $B$. tridactylus have been entirely lost or overexploited, even in conservation units (Parque Estadual do Rio Turvo), confirming that the simple creation of conservation units is not sufficient to ensure the effective protection of biodiversity but also requires adequate management. To reverse the situation, the lands included in conservation units 
277 of integral protection must fully pass to the state through expropriation and compensation, 278 allowing them to be managed and regenerated naturally and/or through management actions. 279 Land tenure regularization depends on the political will to prioritize the allocation of 280 resources, which is difficult to achieve (Schiavetti \& Santos, 2012). The historical economic 281 difficulties in Brazil and the constant trend toward the privatization of conservation units have 282 postponed expropriations. Because of the recent economic crisis caused by the Covid-19 283 pandemic, expropriations may even be absent from the government's agenda for years to come. 284 Brazil is among the nations that have eased conservation actions and laws in the wake of the 285 pandemic (Vale et al., 2021). It is likely that the return to the pre-pandemic state investment in 286 the environment and respect for environmental guidelines by the population will take decades. 287 Since the state has reduced its involvement, environmental violations have increased in the rural 288 population; for example, we heard openly about the daily illegal exploitation of palm hearts by 289 290 291

292

293

294

295

296

297

298

299

300

301

302

303

304

305

306

307

308

309

310

311

312

313

314

315

palmiteiros on an old secondary road (see Díaz et al., 2019).

The areas around the preserved forests (mainly the secondary vegetation) are dominated by the African grass Megathyrsus maximus (Jacq.) B.K.Simon \& S.W.L.Jacobs-a species characterized by dense biomass of great height (up to $3 \mathrm{~m}$ ) — which the communities manage only by fire. Many fires are also caused by cigarettes thrown from vehicles and by uncontrolled burning in fields. These fires gradually enter the forest, first burning the edge, but thereafter killing trees that later become dry biomass for subsequent fires, which can advance further into the forest, and so on. The Atlantic Rainforest is humid, but the mountains are more prone to humidity fluctuations because of the stronger winds, greater intensity of solar radiation, and brighter illumination when clouds are absent (Roderjan, 1994; Rizzini, 1997). The humidity in montane forests can vary widely daily, and periods of low humidity can persist for days, causing water stress in plants (e.g., Roderjan, 1994; Rapp \& Silman, 2012). The synergistic effects of drier years with an increased frequency of fires can favor the movement of forest fires toward pristine mountainous areas, where slopes are accentuated and favor the humidity loss.

Degraded areas dominated by bamboo (Fig. 5E) tend not to advance in natural recovery but regress in their ecological succession when they are dominated by these fast-growing native plants. Because its stems are emitted successively on the branches and tops of native trees, the accumulated weight tends to cause physical damage by breaking the tree branches and trunks, arresting the succession (Griscom \& Ashton, 2006). Areas dominated by bamboo are common in the regions that $B$. tridactylus inhabits. Bamboo may be the habitat of specialist species, such as rats and birds (e.g., Cockle \& Areta, 2013). Of the various bamboo birds that occur in the regions that B. tridactylus inhabits, such as Scytalopus speluncae (taxonomy according Maurício et al., [2010]), Anabazenops fuscus, and Biatas nigropectus (M Bornschein et al., 2021, pers. obs.), the latter two occur particularly in conjunction with Guadua angustifolia Kunth, which is common in the region of occurrence of B. tridactylus. Biatas nigropectus has been identified by IUCN as threatened with extinction (BirdLife International, 2018) and described as Vulnerable, but it is not threatened according to the Brazilian list ("Portaria MMA No 444", December 17, 2014);

Peer) reviewing PDF | (2021:07:63242:2:0:NEW 23 Nov 2021) 
316 thus, there are no requirements for the management of bamboo because of its potential

317 occupation by endangered species.

318 We suggest intensifying private sector involvement and directing resources from

319 environmental fines as a way to solve environmental problems in the Parque Estadual do Rio

320 Turvo. The degraded area in this conservation unit over $715 \mathrm{~m}$ a.s.l., which meets the altitudinal

321 criterion regarding the area of occupancy of $B$. tridactylus, covers $17.2 \mathrm{~km}^{2}$. This is the extent of

322 area that could be reclaimed to support the improved geographic distribution of the species.

323

324

325

\section{Conservation Measures Proposed}

We recommend conservation management on three fronts: 1) the formation of fire brigades, 2)

326 the management of residents' mules in conservation units and surrounding areas, and 3) the

327

328

329

330

331

332

333

334

335

336

337

338

339

340

341

342

343

344

345

346

347

348

349

350

351

352

353

354

355 management of degraded areas. Permanent firefighting teams would prevent fires by introducing fire-breaks. Secondary vegetation areas are burned every year or at intervals of two or three years in winter, especially in July and August, and in extremely hot summer months (e.g., February). Fires are abundant near communities and along several kilometers of the BR 116 highway (Fig. $5 \mathrm{~A}, \mathrm{~B})$.

We suggest placing microchips and sealed radio collars on the residents' mules in the Parque Estadual do Rio Turvo and surrounding areas to control the activities of palmiteiros and reduce the impact of animals on vegetation through monitoring. The data gathered by the radio collars should be downloaded regularly and analyzed to check the animals' movements. This proposal must be supported by public policy that would allow the monitoring of animals. Moreover, it must be conducted in partnership with the local police, who would be able to act on proof that mules were entering the state park.

Regarding the management of degraded areas, we propose an intervention on two fronts: sowing degraded areas and reducing bamboo biomass to facilitate subsequent sowing. We propose the sowing of seeds directly by men in the field or by air in two stages: 1) an initial intervention and 2) when the sown vegetation has grown to $1.5 \mathrm{~m}$ to $2 \mathrm{~m}$ in height around two to four years after sowing. For the first intervention, we propose sowing seeds of the Leandra australis (Cham.) Cogn. and Piper aduncum L. shrubs in combination with three to six trees species from Alchornea glandulosa Poepp. \& Endl., A. triplinervia (Spreng.) Müll.Arg., Citharexylum myrianthum Cham., Miconia cinerascens Miq., M. cinnamomifolia (DC.) Naudin, M. formosa Cogn., Myrsine coriacea (Sw.) R.Br. ex Roem. \& Schult., Psidium guajava L., Schizolobium parahyba (Vell.) Blake, Senna multijuga (Rich.) H.S.Irwin \& Barneby, Tibouchina pulchra Cogn., Trema micrantha (L.) Blume, and Vochysia bifalcata Warm. The shrubs have excellent coverage and would help to reduce the dominance of the African grass M. maximus. For the second intervention, we propose dispersing seeds from trees grown in the first intervention, particularly $A$. glandulosa and A. triplinervia. We also suggest incorporating seeds from the trees Didymopanax morototoni (Aubl.) Decne. \& Planch., Hyeronima alchorneoides Allemão, and Piptadenia gonoacantha (Mart.) J.F.Macbr., as well as palm seeds from Syagrus romanzoffiana (Cham.) Glassman. Additional sowing should be evaluated in loco according to 
356

357

358

359

360

361

362

363

364

365

366

367

368

369

370

371

372

373

374

375

376

377

378

379

380

381

382

383

384

385

386

387

388

389

390

391

392

393

394

vegetation development. In the event of fires in the intervention areas, the first stage would be repeated.

We suggest prioritizing recovery areas that are dominated by bamboo on the margins of forests in a good stage of conservation and/or close to places where there are regular fires. It would be necessary to construct a grid of trails (perhaps $5 \mathrm{~m}$ from each other) using scythes to cut the bamboo at the base. This process should be repeated every three months to cut the new shoots while they are still soft. As the bamboo biomass starts to decompose and access between the parallel trails becomes easier, the bases of the remaining bamboo should be cut, and sowing should then begin as described above.

\section{Conclusions}

Brachycephalus tridactylus is currently threatened with extinction especially due to its restricted geographic distribution caused by habitat reduction and the loss of habitat quality. Despite this, this species has a high density and a high population size, like the congeners for which these data are available. The conservation of this small toadlet requires local measures, such as the restoration of degraded areas, as well as comprehensive actions, such as cultural changes regarding the use of fire as an agricultural practice. Furthermore, the chain of action proposed for conservation should include both local communities and the state, including the development of public policy. These actions and their effects could go beyond the area of occupancy of the species, benefiting many other species; therefore, we propose the concept of a fountain species that includes small species, the conservation of which would affect many flora and fauna, like a source of water that is local but spreads widely.

\section{Acknowledgements}

Tamiris Pereira-Lima and Andre Leite helped with the fieldwork. The managers of Núcleo Capelinha in the Parque Estadual do Rio Turvo provided accommodation and logistical support during the fieldwork in Serra do Pinheiro. Kelsey Neam and two anonymous reviewer made valuable comments that improved the quality of the text.

\section{References}

BirdLife International. 2018. Biatas nigropectus. The IUCN Red List of Threatened Species 2018. Acessed: 3 April 2018. Acessible at: doi:10.2305/IUCN.UK.2018-

2.RLTS.T22701272A131290691

Bornschein M.R. 2015. Some trees do not necessarily mean a forest: a criticism to Ramos and Anjos 2014. Natureza \& Conservação 13(2):204-206. doi:10.1016/j.ncon.2015.10.002

Bornschein M.R., Belmonte-Lopes R., Ribeiro L.F., Maurício G.N., Pie, M.R. 2015a. Rectification of the position of the type locality of Brachycephalus tridactylus (Anura: Brachycephalidae), a recently described species from southern Brazil. Zootaxa 4007(1):149150. doi:10.11646/zootaxa.4007.1.14 
395

396

397

398

399

400

401

402

403

404

405

406

407

408

409

410

411

412

413

414

415

416

417

418

419

420

421

422

423

424

425

426

427

428

429

430

431

432

433

Bornschein M.R., Firkowski C.R., Baldo D., Ribeiro L.F., Belmonte-Lopes R., Corrêa L., Morato S.A.A., Pie M.R. 2015b. Three new species of phytotelm-breeding Melanophryniscus from the Atlantic Rainforest of southern Brazil (Anura: Bufonidae). PLoS ONE 10(12):e0142791. doi:10.1371/journal.pone.0142791

Bornschein, M.R., Firkowski C.R., Belmonte-Lopes R., Corrêa L., Ribeiro L.F., Morato S.A.A., Antoniazzi-Jr. R.L., Reinert B.L., Meyer A.L.S., Cini F.A., Pie M.R. 2016a. Geographic and altitudinal distribution of Brachycephalus Fitzinger (Anura: Brachycephalidae) endemic to the Brazilian Atlantic Rainforest. PeerJ 4:e2490. doi:10.7717/peerj.2490

Bornschein M.R., Ribeiro L.F., Blackburn D.C., Stanley E.L., Pie, M.R. 2016b. A new species of Brachycephalus (Anura: Brachycephalidae) from Santa Catarina, southern Brazil. PeerJ 4:e2629. doi:10.7717/peerj.2629

Bornschein M.R., Ribeiro L.F., Pie, M.R. 2021. Reassessing overlooked information about the diagnosis of Brachycephalus atelopoide (Anura: Brachycephalidae), a neglected problem for the taxonomy of the genus. Phyllomedusa 20(1):109-115. doi:10.11606/issn.23169079.v20i1p109-115

Bornschein M.R., Pie M.R., Teixeira L. 2019. Conservation status of Brachycephalus toadlets (Anura: Brachycephalidae) from the Brazilian Atlantic Rainforest. Diversity 11(150):1-29. doi:10.3390/d11090150

Bornschein M.R., Teixeira L., Ribeiro L.F. 2019. New record of Brachycephalus fuscolineatus Pie, Bornschein, Firkowski, Belmonte-Lopes \& Ribeiro, 2015 (Anura, Brachycephalidae) from Santa Catarina state, Brazil. Check List 15(3):379-385. doi:10.15560/15.3.379

Bornschein M.R., Rollo M.M. Jr., Pie M.R., Confetti A.E., Ribeiro L.F. 2019a. Redescription of the advertisement call of Brachycephalus tridactylus (Anura: Brachycephalidae).

Phyllomedusa 18(1):3-12. doi:10.11606/issn.2316-9079.v18i1p3-12

Bornschein M.R., Ribeiro L.F., Teixeira L., Pie M.R. 2019b. New altitudinal record for Brachycephalus actaeus Monteiro, Condez, Garcia, Comitti, Amaral \& Haddad, 2018 (Anura, Brachycephalidae), with comments on its habitats of occurrence. Check List 15(6):1031-1036. doi:10.15560/15.6.1031

Bornschein M.R., Ribeiro L.F., Teixeira L., Belmonte-Lopes R., Moraes L.A. de, Corrêa L., Maurício G.N., Nadaline J., Pie M.R. 2021. A review of the diagnosis and geographical distribution of the recently described flea toad Brachycephalus sulfuratus in relation to $B$. hermogenesi (Anura: Brachycephalidae). PeerJ 9:e10983. doi:10.7717/peerj.10983

Carnaval A.C., Waltari E., Rodrigues M.T., Rosauer D., VanDerWal J., Damasceno R., Prates I., Strangas M., Spanos Z., Rivera D., Pie M.R., Firkowski C.R., Bornschein M.R., Ribeiro L.F., Moritz C. 2014. Prediction of phylogeographic endemism in an environmentally complex biome. Proceedings of the Royal Society B: Biological Sciences 281:20141461. doi:10.1098/rspb.2014.1461

Cockle K.L., Areta J.I. 2013. Specialization on bamboo by Neotropical birds. The Condor 115(2):217-220. doi:10.1525/cond.2013.120067 
434 Condez T.H., Clemente-Carvalho R.B.G., Haddad, C.F.B, dos Reis, S.F. 2014. A new species of

435

436

437

438

439

440

441

442

443

444

445

446

447

448

449

450

451

452

453

454

455

456

457

458

459

460

461

462

463

464

465

466

467

468

469

470

471

472

Brachycephalus (Anura: Brachycephalidae) from the highlands of the Atlantic Forest, Southeastern Brazil. Herpetologica, 70(1):89-99. doi:10.1655/HERPETOLOGICA-D-1300044

Condez T.H., Haddad C.F.B., Zamudio K.R. 2020. Historical biogeography and multi-trait evolution in miniature toadlets of the genus Brachycephalus (Anura: Brachycephalidae). Biological Journal of the Linnean Society 129(3):664-686. doi:10.1093/biolinnean/blz200

Condez T.H., Monteiro J.P. de C, Mlagoli L.R., Trevine V.C., Schunck F., Garcia P.C.A., Haddad C.F.B. 2021. Notes on the hyperossified pumpkin toadlets of the genus Brachycephalus (Anura: Brachycephalidae) with the description of a new species. Herpetologica 77(2):176-194. doi:10.1655/HERPETOLOGICA-D-20-00031

Díaz S., Settele J., Brondízio E.S., Ngo H.T., Agard J., Arneth A., Balvanera P., Brauman K.A., Butchart S.H.M., Chan K.M.A., Garibaldi L.A., Ichii K., Liu J., Subramanian S.M., Midgley G.F., Miloslavich P., Molnár Z., Obura D., Pfaff A., Polasky S., Purvis A., Razzaque J., Reyers B., Chowdhury R.R., Shin Y.J., Visseren-Hamakers I., Willis K.J., Zayas C.N. 2019. Pervasive human-driven decline of life on Earth points to the need for transformative change. Science 366:1327. doi:10.1126/science.aax3100

Firkowski C.R., Bornschein M.R., Ribeiro L.F., Pie M.R. 2016. Species delimitation, phylogeny and evolutionary demography of co-distributed, montane frogs in the southern Brazilian Atlantic Forest. Molecular Phylogenetics and Evolution 100:345-360. doi:10.1016/j.ympev.2016.04.023

Frost D.R. 2021. Amphibian Species of the World 6.1. Available at https://amphibiansoftheworld.amnh.org/ (accessed 11 September 2021).

Garey M.V., Lima A.M.X., Hartmann M.T., Haddad C.F.B. 2012. A new species of miniaturized toadlet, genus Brachycephalus (Anura: Brachycephalidae), from Southern Brazil. Herpetologica, 68:266-271. doi:10.1655/HERPETOLOGICA-D-11-00074.1

Garey M.V., Provete D.B. 2016. Species composition, conservation status, and sources of threat of anurans in mosaics of highland grasslands of southern and southeastern Brazil. Oecoloogia Australis 20(2):232-246. doi:10.4257/oeco.2016.2002.07

Griscom B.W., Ashton P.M.S. 2006. A self-perpetuating bamboo disturbance cycle in a neotropical forest. Journal of Tropical Ecology 22:287-297. doi:10.1017/S0266467406003361

IUCN. 2012. IUCN Red List Categories and Criteria: Version 3.1., 2nd ed. International Union for Conservation of Nature-IUCN, Gland and Cambridge.

IUCN Standards and Petitions Committee. 2019. Guidelines for Using the IUCN Red List Categories and Criteria. Version 14. Standards and Petitions Committee, Gland and Cambridge.

Magnago L.F.S., Rocha M.F., Meyer L., Martins S.V., Meira-Neto J.A.A. 2015. Microclimatic conditions at forest edges have significant impacts on vegetation structure in large Atlantic

Peer) reviewing PDF | (2021:07:63242:2:0:NEW 23 Nov 2021) 
473

474

475

476

477

478

479

480

481

482

483

484

485

486

487

488

489

490

491

492

493

494

495

496

497

498

499

500

501

502

503

504

505

506

507

508

509

510

511

512

Forest fragments. Biodiversity and Conservation 24(9):2305-2318. doi:10.1007/s10531015-0961-1

Maurício G.N., Bornschein M.R., Vasconcelos M.F. de, Whitney B.M., Pacheco J.F., Silveira L.F. 2010. Taxonomy of "Mouse-colored Tapaculos". I. On the application of the name Malacorhynchus speluncae Ménétriés, 1835 (Aves: Passeriformes: Rhinocryptidae). Zootaxa 2518:32-48. doi:10.11646/zootaxa.2518.1.2

McCormack J.E., Huang H., Knowles L.L. 2009. Sky islands. Pp. 839-843, in: Gillespie R.G., Clague D. (Eds.), Encyclopedia of islands. University of California Press, Berkeley.

Mohr C.O. 1947. Table of equivalent populations of North American small mammals. American Midland Naturalist 37(1):223-249. doi:10.2307/2421652

Nunes I., Guimarães C.S., Moura P.H.A.G., Pedrozo M., Moroti M. de T., Castro L.M., Stuginscki D.R., Muscat E. 2021. Hidden by the name: A new fluorescent pumpkin toadlet from the Brachycephalus ephippium group (Anura: Brachycephalidae). PLoS ONE 16(4):e0244812. doi:10.1371/journal.pone.0244812

Oliveira F.F.R. de, MircoSolé M.G., Lyra M., Haddad C.F.B., Silva D.P., Magalhães R.F. de, Leite F.S.F., Burbrink F.T. 2021. Quaternary climatic fluctuations influence the demographic history of two species of sky-island endemic amphibians in the Neotropics. Molecular Phylogenetics and Evolution 160:107113. doi:10.1016/j.ympev.2021.107113

Pie M.R., Faircloth B.C., Ribeiro L.F., Bornschein M.R. \& McCormack J.E. $2018 \mathrm{a}$. Phylogenomics of montane frogs of the Brazilian Atlantic Forest is consistent with isolation in sky islands followed by climatic stability. Biological Journal of the Linnean Society 125:72-82. doi:10.1093/biolinnean/bly093

Pie M.R., Ribeiro L.F., Confetti A.E., Nadaline M.J. \& Bornschein M.R. 2018b. A new species of Brachycephalus (Anura: Brachycephalidae) from southern Brazil. PeerJ 6:e5683. doi:org/10.7717/peerj.5683

Pie M.R., Meyer A.L.S., Firkowski C.R., Ribeiro L.F., Bornschein M.R. 2013. Understanding the mechanisms underlying the distribution of microendemic montane frogs (Brachycephalus spp., Terrarana: Brachycephalidae) in the Brazilian Atlantic Rainforest. Ecological Modelling 250:165-176. doi:10.1016/j.ecolmodel.2012.10.019

Pie M.R. and Ribeiro L.F. 2015. A new species of Brachycephalus (Anura: Brachycephalidae) from the Quiriri mountain range of southern Brazil. PeerJ 3:e1179. doi:10.7717/peerj.1179

Pombal Jr J.P., Gasparini J.L. 2006. A new Brachycephalus (Anura: Brachycephalidae) from the Atlantic Rainforest of Espírito Santo, Southeastern Brazil. South American Journal of Herpetology 1(2):87-93. doi:10.2994/1808-9798(2006)1[87:ANBABF]2.0.CO;2

Pulido-Santacruz P., Bornschein M.R., Belmonte-Lopes R., Bonatto S.L. 2016. Multiple evolutionary units and demographic stability during the last glacial maximum in the Scytalopus speluncae complex (Aves: Rhinocryptidae). Molecular Phylogenetics and Evolution 102:86-96. doi:10.1016/j.ympev.2016.05.027

Rapp J.M., Silman M.R. 2012. Diurnal, seasonal, and altitudinal trends in microclimate across a tropical montane cloud forest. Climate Research 55(1):17-32. doi:10.3354/cr01127 
513 Reinert B.L., Bornschein M.R., Firkowski C. 2007. Distribuição, tamanho populacional, hábitat 514 e conservação do bicudinho-do-brejo Stymphalornis acutirostris Bornschein, Reinert e 515 Teixeira, 1995 (Thamnophilidae). Revista Brasileira de Ornitologia 15(4):493-519.

516 Ribeiro L.F., Blackburn D.C., Stanley E.L., Pie M.R, Bornschein M.R. 2017. Two new species

517 of the Brachycephalus pernix group (Anura: Brachycephalidae) from the state of Paraná, 518 southern Brazil. PeerJ 5:e3603. doi:org/10.7717/peerj.3603

519 Ribeiro L.F., Bornschein M.R., Belmonte-Lopes R., Firkowski C.R., Morato S.A.A., Pie M.R. 520 2015. Seven new microendemic species of Brachycephalus (Anura: Brachycephalidae) from

521

522

523

524

525

526

527

528

529

530

531

532

533

534

535

536

537

538

539

540 southern Brazil. PeerJ 3:e1011. doi:10.7717/peerj.1011

Rizzini C.T. 1997. Tratado de fitogeografia do Brasil: aspectos ecológicos, sociológicos e florísticos, 2nd ed. Âmbito Cultural Edições Ltda, Rio de Janeiro.

Roderjan C.V. 1994. O gradiente da Floresta Ombrófila Densa no Morro Anhangava, Quatro Barras, PR - aspectos climáticos, pedológicos e fitossociológicos. PhD Dissertation, Universidade Federal do Paraná, Brazil.

Schiavetti A.M.T.C., Santos M.S. 2012. Implementação das unidades de conservação do corredor central da Mata Atlântica no estado da Bahia: desafios e limites. Revista Árvore 36(4):611-623. doi:10.1590/S0100-67622012000400004

Tapley B., Michaels C.J., Gumbs R., Böhm M., Luedtke J., Pearce-Kelly P., Rowley J.J.L. 2018. The disparity between species description and conservation assessment: A case study in taxa with high rates of species discovery. Biological Conservation 220: 209-214. doi:10.1016/j.biocon.2018.01.022

Vale M.M., Berenguer E., Menezes M.A., Castro E.B.V., Siqueira L.P., Portela R.C.Q. 2021. The COVID-19 pandemic as an opportunity to weaken environmental protection in Brazil. Biological Conservation:108994. doi:10.1016/j.biocon.2021.108994

Veloso H.P., Rangel-Filho A.L.R., Lima J.C.A. 1991. Classificacão da vegetacão brasileira, adaptada a um sistema universal. Instituto Brasileiro de Geografia e Estatística - IBGE, Rio de Janeiro. 


\section{Figure 1}

Figure 1. Target region for the search for new populations of Brachycephalus tridactylus divided into circles with radiuses of 10-60 km from the type locality of the species (Bornschein et al., 2015a) and subdivided every $90^{\circ}$.

The colored polygons represent the approximate distribution of the Dense Ombrophilous Forest above $700 \mathrm{~m}(+/-20 \mathrm{~m})$ above sea level (a.s.l.). The portions of the environment in each quadrant in which we carried out at least one field trip are shown in green, and the portions of the environment in each quadrant in which we did not carry out field trips are shown in red. Image sources: Esri, United States Geological Survey (USGS), National Geospatial-Intelligence Agency (NGA), National Aeronautics and Space Administration (NASA), and the GIS user community. 


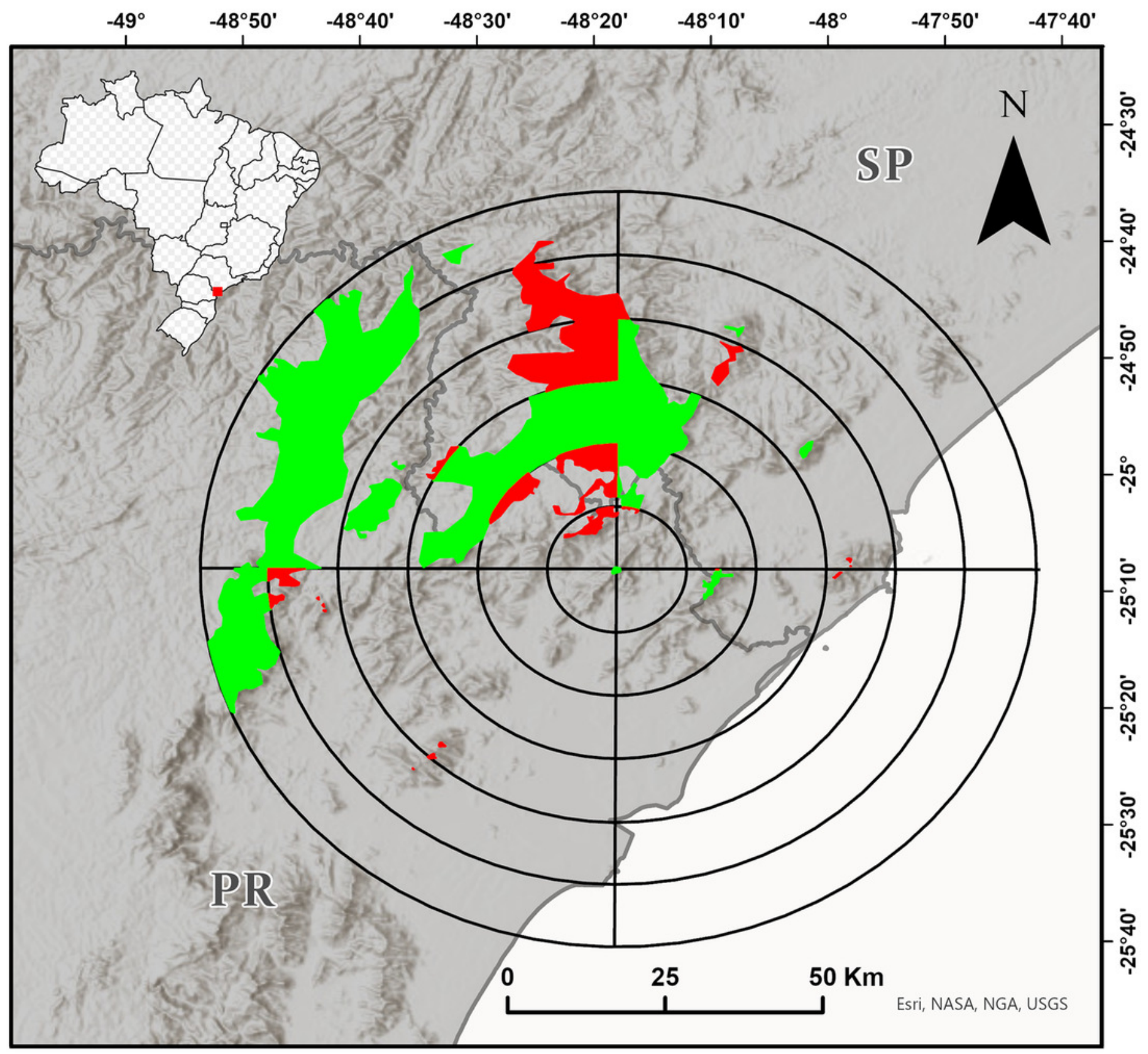




\section{Figure 2}

Figure 2. Geographical distribution of Brachycephalus tridactylus (stars) in southeastern and southern Brazil.

Type locality (red star) according to Bornschein et al. (2015). Abbreviations: SP = São Paulo;

PR = Paraná. Image sources: Esri, Airbus Defence and Space (Airbus DS), United States

Geological Survey (USGS), National Geospatial-Intelligence Agency (NGA), National Aeronautics and Space Administration (NASA), Consultative Group on International Agricultural Research (CGIAR), N Robinson, National Center for Ecological Analysis and Synthesis (NCEAS), National Library Service (NLS), Ordnance Survey (OS), New Masters Academy (NMA), Geodatatyrelsen, Rijkswaterstaat, GSA Technology Deployment Maps, Geoland, Federal Emergency Mgmt Agency (FEMA), Intermap, and the GIS user community. 


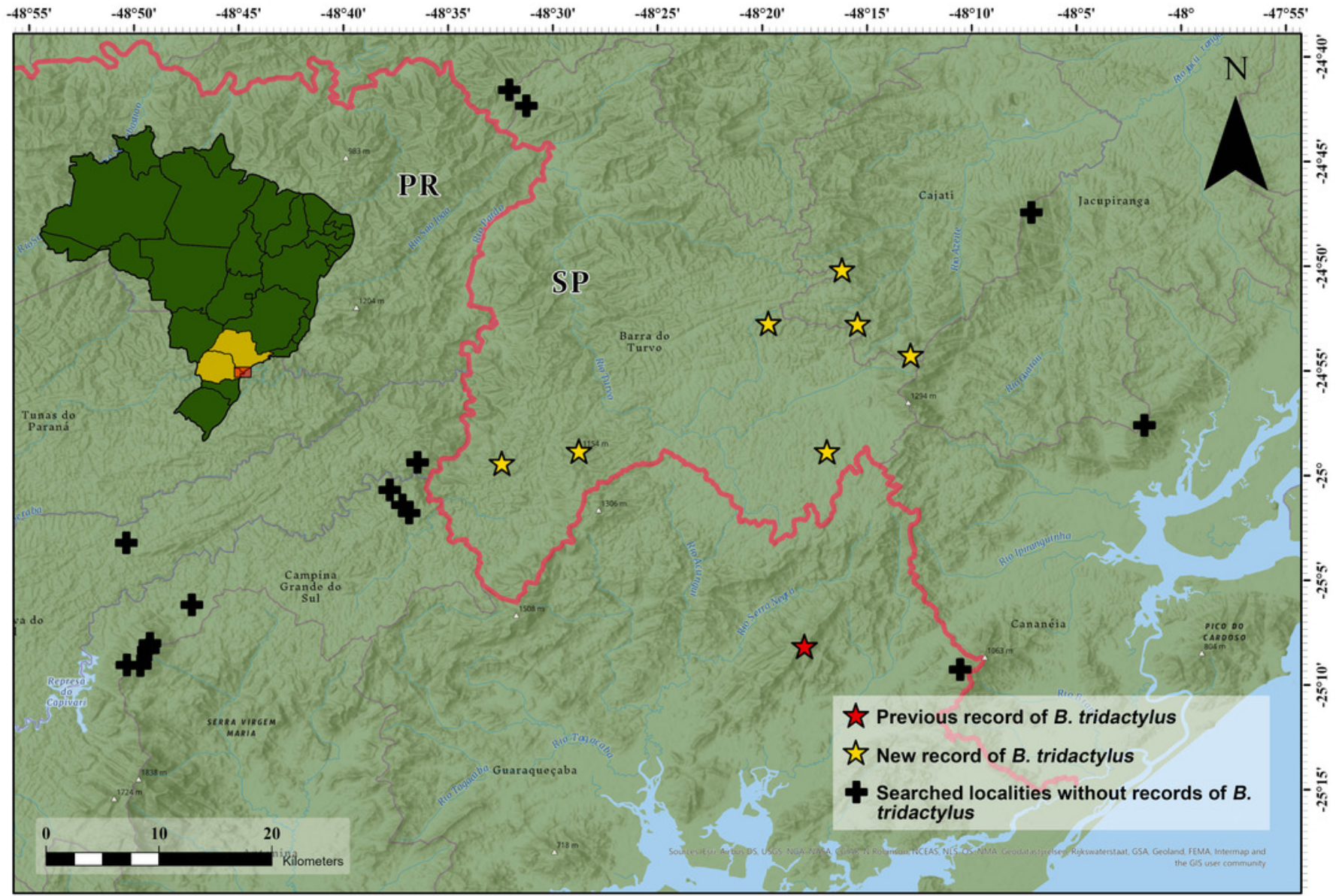




\section{Figure 3}

Figure 3. Brachycephalus tridactylus from Morro do Bisel (A), Cajati, São Paulo (MHNCl 11637) compared with one individual from its type locality (Reserva Natural Salto Morato [B], Guaraqueçaba, Paraná [CFBH 43887]).

Photographs: Luiz F. Ribeiro.

A

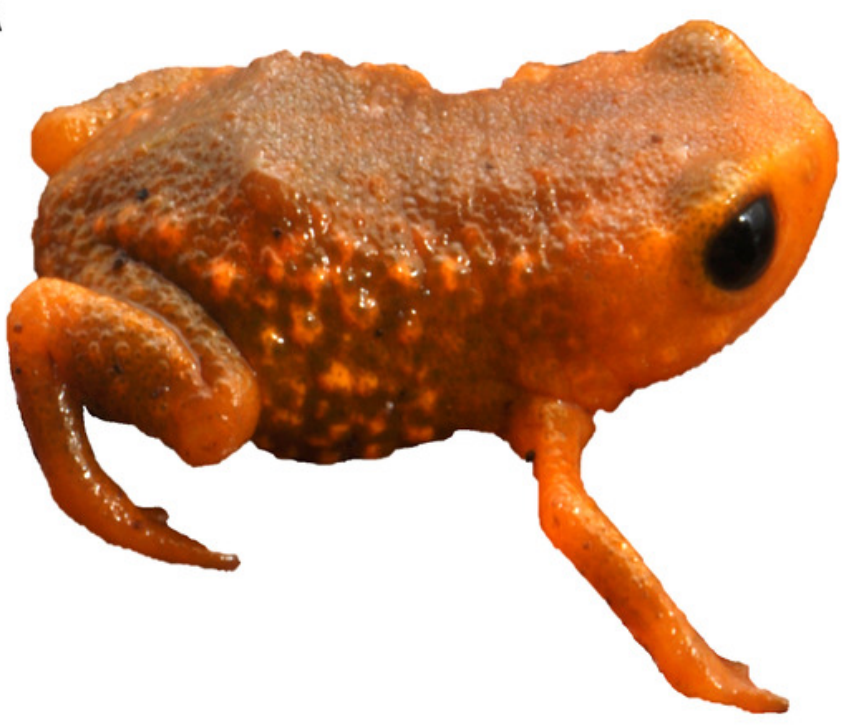

B

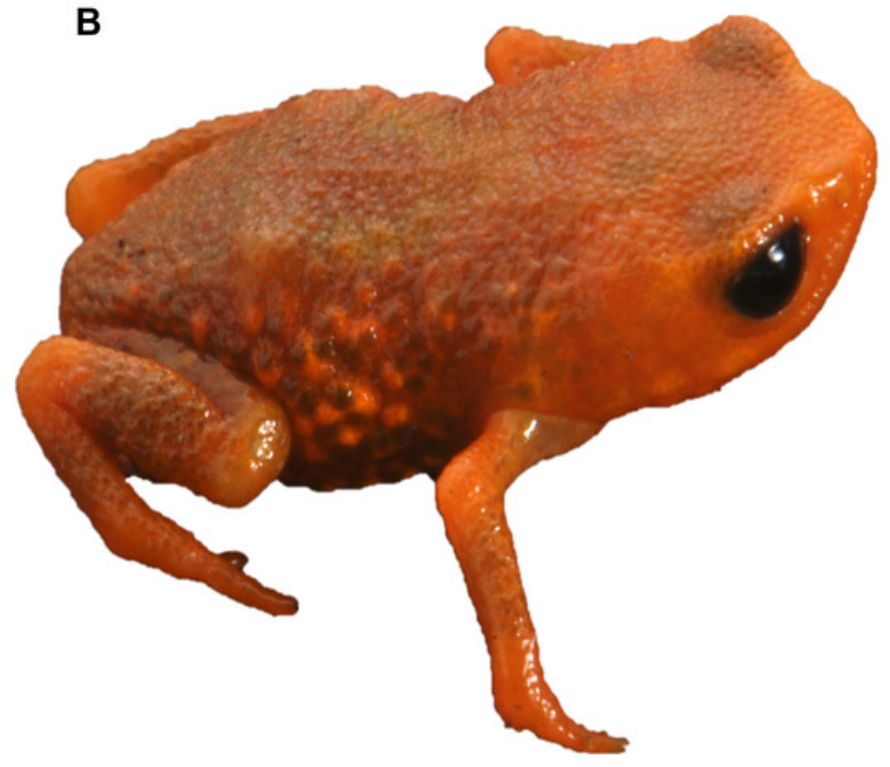




\section{Figure 4}

Figure 4. Area of occupancy of Brachycephalus tridactylus (light gray polygons) inside the minimum convex polygon connecting (solid white line) the extreme records in southeastern and southern Brazil.

The white dashed line represents the state border between São Paulo (northeastern portion) and Paraná. Image sources: Esri, DigitalGlobe, GeoEye, Earthstar Geographics, Centre National d'Etudes Spatiales (CNES)/ Airbus Defence and Space (Airbus DS), United States Department of Agriculture (USDA), United States Geological Survey (USGS), AeroGRID, Institut Geographique National (IGN), and the GIS user community. 


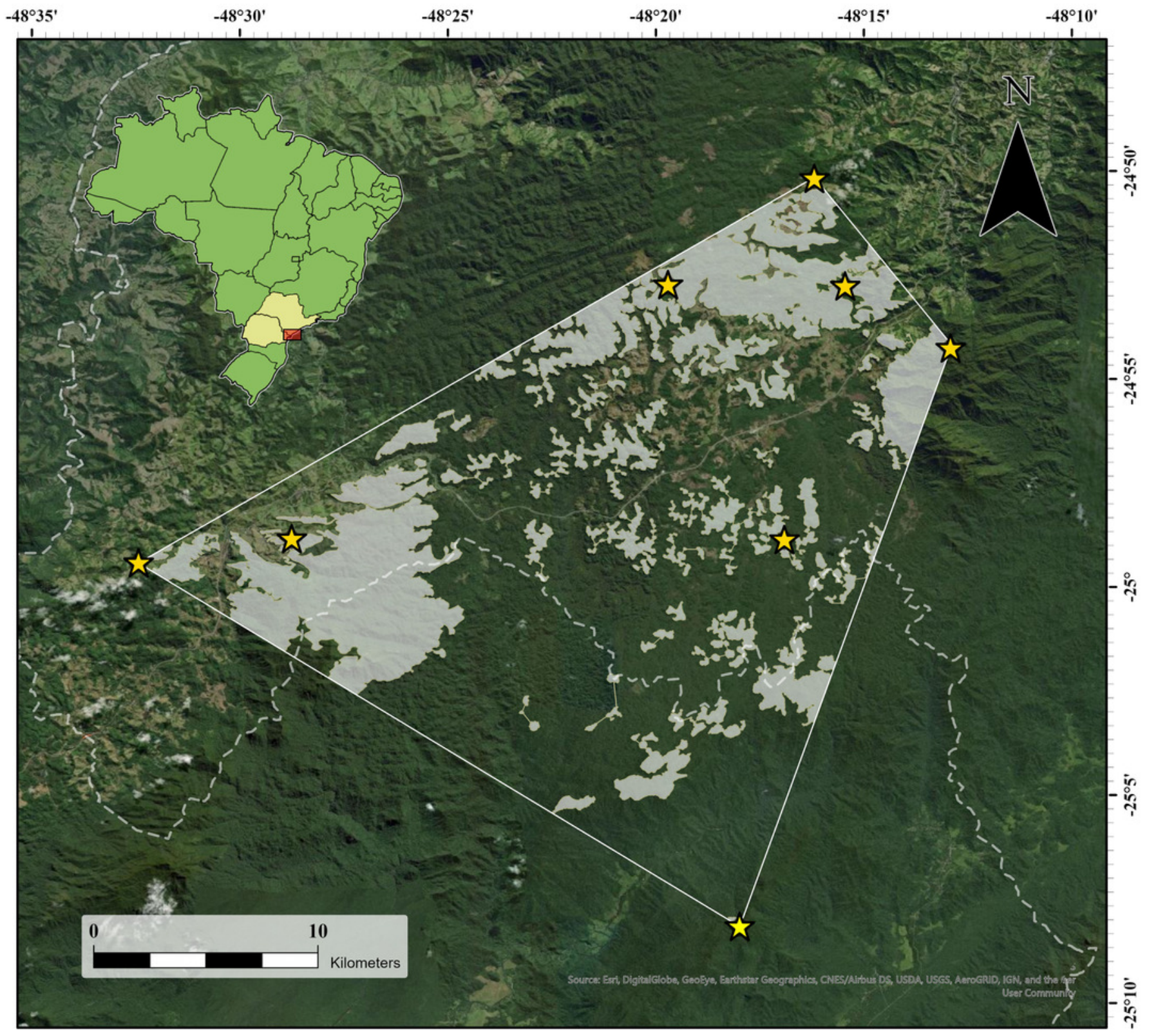




\section{Figure 5}

Figure 5. Habitat loss of Brachycephalus tridactylus in the Parque Estadual do Rio Turvo, São Paulo.

A. A general view of the landscape around the BR 116 highway (crossing the second plane from left to right), highlighting deforested areas that are maintained by regular fires. B. Close-up view of pastures maintained by fire. C. A forest greatly altered by fire, wood logging, and edge effects. D . A forest deeply altered by wind. E. Secondary vegetation with ecological succession impaired by dense bamboo cover. F. Arboreal vegetation destroyed by fire. Photographs: Marcos R. Bornschein (2019). 

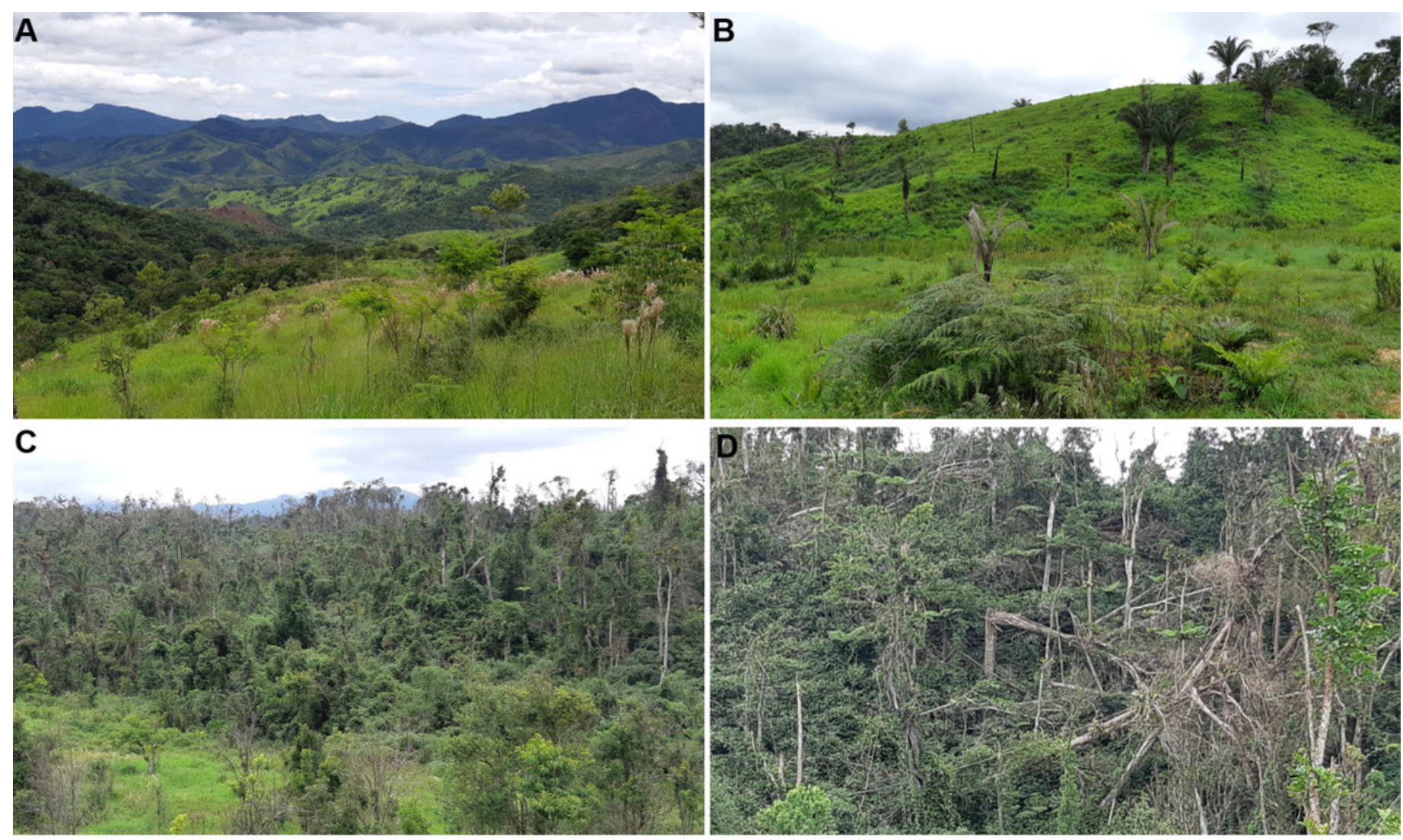

E

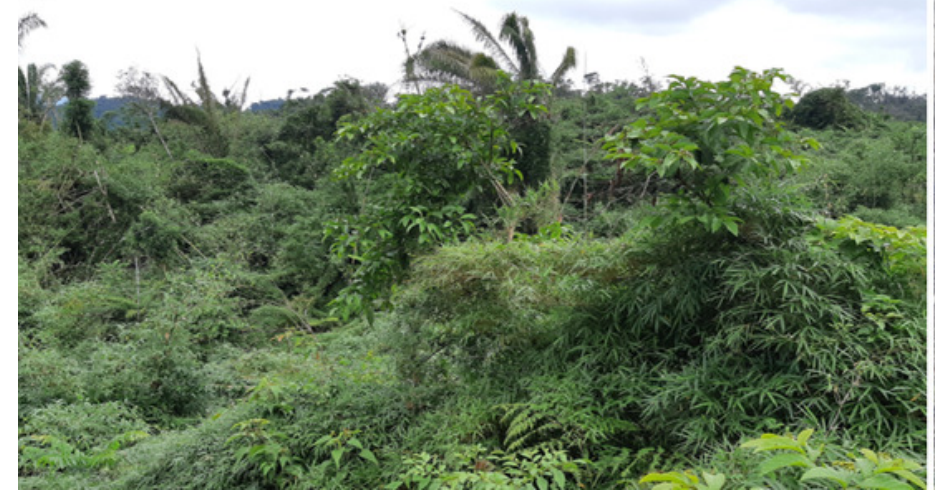

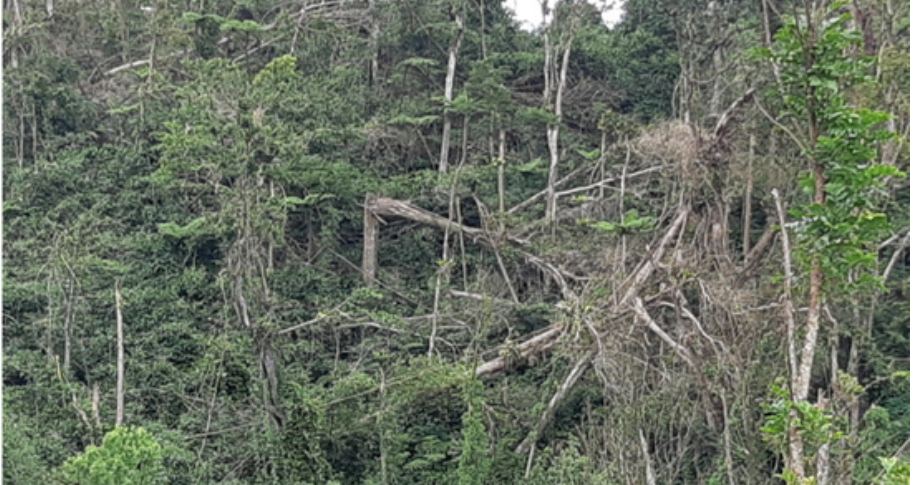

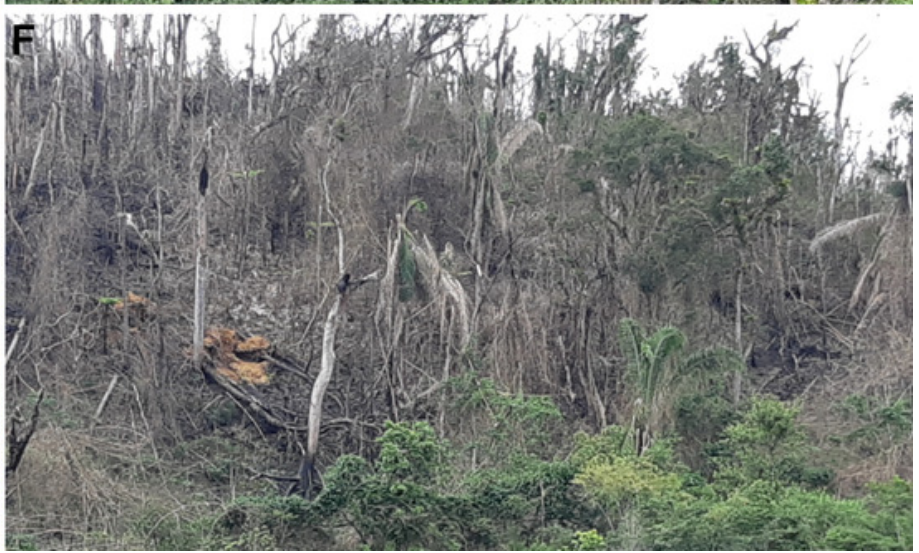




\section{Figure 6}

Figure 6. Intense illegal palm heart cutting (of Euterpe edulis) by palmiteiros along an old rural road in a region with records of Brachycephalus tridactylus in the Parque Estadual do Rio Turvo, São Paulo.

A. Palmiteiro with one of two mules bearing a load of about 60 palm hearts. B. The palmiteiro's second mule also carrying a load of about 60 palm hearts. C. Characteristic mud formed by the frequent passage of mules, making depressions where their feet step between elevations that correspond to the length of their strides. D. About 55 palm hearts left on the edge of the rural road because of the rupture of the ropes supporting the load on a mule. Photographs: Marcos R. Bornschein (2019).
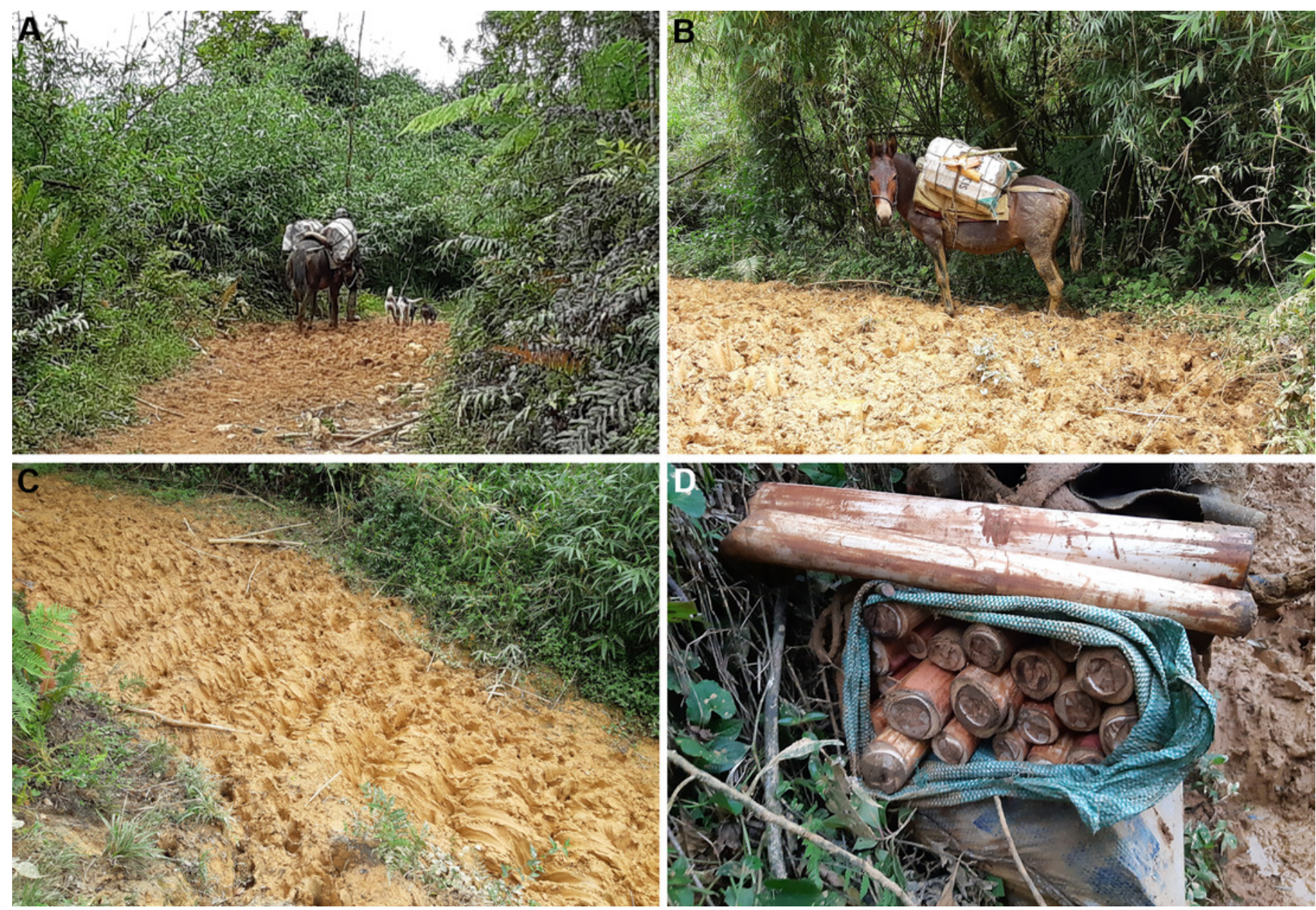


\section{Table $\mathbf{1}$ (on next page)}

Table 1. New localities of records of Brachycephalus tridactylus searched from 2016-2020.

Abbreviation: $\mathrm{MHNCl}=$ Museu de História Natural Capão da Imbuia, Curitiba, Paraná, Brazil. 
Table 1. New localities of records of Brachycephalus tridactylus searched from 2016-2020. Abbreviation: MHNCI = Museu de

2 História Natural Capão da Imbuia, Curitiba, Paraná, Brazil.

\begin{tabular}{|c|c|c|c|c|c|}
\hline \multirow[b]{2}{*}{ Locality } & \multirow[b]{2}{*}{$\begin{array}{l}\text { Geographic } \\
\text { coordinates }^{1}\end{array}$} & \multicolumn{3}{|c|}{ Altitude (m) above sea level } & \multirow[b]{2}{*}{ Voucher } \\
\hline & & $\begin{array}{l}\text { Searched } \\
\text { for the } \\
\text { species }\end{array}$ & With forests & $\begin{array}{l}\text { Records of the } \\
\text { species }\end{array}$ & \\
\hline $\begin{array}{l}\text { Bairro Rio Vermelho, Parque Estadual } \\
\text { do Rio Turvo, municipality of Barra do } \\
\text { Turvo, São Paulo }\end{array}$ & $\begin{array}{l}\text { 2459'25”S, } \\
48^{\circ} 32^{\prime} 26^{\prime \prime} \mathrm{W}\end{array}$ & $660-835$ & $770-820$ & $770-790$ & MHNCI 11643-45 \\
\hline $\begin{array}{l}\text { Estrada das Conchas, Parque Estadual } \\
\text { do Rio Turvo, municipality of Barra do } \\
\text { Turvo, São Paulo }\end{array}$ & $\begin{array}{l}24^{\circ} 52^{\prime} 44^{\prime \prime} \mathrm{S} \\
48^{\circ} 19^{\prime} 42^{\prime \prime} \mathrm{W}\end{array}$ & $695-850$ & $750-850$ & $800-850$ & $\begin{array}{l}\text { MHNCI } 11642 \text { and } \\
\text { recordings }\end{array}$ \\
\hline $\begin{array}{l}\text { Fazenda Fronteira, Parque Estadual do } \\
\text { Rio Turvo, municipality of Barra do } \\
\text { Turvo, São Paulo }\end{array}$ & $\begin{array}{l}24^{\circ} 58^{\prime} 52^{\prime \prime} \mathrm{S} \\
48^{\circ} 16^{\prime} 54^{\prime \prime} \mathrm{W}\end{array}$ & $680-730$ & $690-730$ & $715-725$ & $\begin{array}{l}\text { MHNCI } 11648-50, \text { three } \\
\text { uncataloged specimens, } \\
\text { and recordings }\end{array}$ \\
\hline $\begin{array}{l}\text { Morro do Bisel, Serra do Guaraú, } \\
\text { Parque Estadual do Rio Turvo, } \\
\text { municipality of Cajati, São Paulo }\end{array}$ & $\begin{array}{l}24^{\circ} 54^{\prime} 15^{\prime \prime} \mathrm{S} \\
48^{\circ} 12^{\prime} 55^{\prime \prime} \mathrm{W}\end{array}$ & $650-1,060$ & $650-1,060$ & $800-1,060$ & $\begin{array}{l}\text { MHNCI } 11637 \text { and } \\
\text { recordings }\end{array}$ \\
\hline $\begin{array}{l}\text { Serra do Pinheiro, Parque Estadual do } \\
\text { Rio Turvo, municipality of Cajati, São } \\
\text { Paulo }\end{array}$ & $\begin{array}{l}24^{\circ} 50^{\prime} 11^{\prime \prime} \mathrm{S} \\
48^{\circ} 16^{\prime} 11^{\prime \prime} \mathrm{W}\end{array}$ & $295-810$ & $770-775$ & 775 & $\begin{array}{l}\text { MHNCI } 11638-41 \text { and } \\
\text { recordings }\end{array}$ \\
\hline $\begin{array}{l}\text { Serra Pelada, Parque Estadual do Rio } \\
\text { Turvo, municipality of Barra do Turvo, } \\
\text { São Paulo }\end{array}$ & $\begin{array}{l}24^{\circ} 58^{\prime} 50^{\prime \prime} \mathrm{S} \\
48^{\circ} 28^{\prime} 45^{\prime \prime} \mathrm{W}\end{array}$ & $740-1,140$ & $1,130-1,140$ & $1,130-1,140$ & $\begin{array}{l}\text { MHNCI } 11571,11646-47 \text {, } \\
\text { one uncataloged specimen, } \\
\text { and recordings }\end{array}$ \\
\hline $\begin{array}{l}\text { Torre Embratel, Parque Estadual do Rio } \\
\text { Turvo, municipality of Cajati, São } \\
\text { Paulo }\end{array}$ & $\begin{array}{l}24^{\circ} 52^{\prime} 46^{\prime \prime} \mathrm{S} \\
48^{\circ} 15^{\prime} 27^{\prime \prime} \mathrm{W}\end{array}$ & $950-1,000$ & $950-1,000$ & $960-990$ & $\begin{array}{l}\text { MHNCI 10848, 10852, } \\
\text { 11630-36, } 11 \text { uncataloged } \\
\text { specimens, and recordings }\end{array}$ \\
\hline
\end{tabular}

DATUM WGS84. 